\title{
TLE2 wt Allele
}

National Cancer Institute

\section{Source}

National Cancer Institute. TLE2 wt Allele. NCI Thesaurus. Code C115081.

Human TLE2 wild-type allele is located in the vicinity of 19p13.3 and is approximately 50 $\mathrm{kb}$ in length. This allele, which encodes transducin-like enhancer protein 2 , plays a role in transcriptional repression. 